\title{
The American Professoriate: A Status Check of Factors and Perceptions
}

\author{
Raymond W. Francis ${ }^{1, *}$, Larry J. Corbett ${ }^{1} \&$ Michael Magarrey ${ }^{1}$ \\ ${ }^{1}$ Center for Excellence in Education, Central Michigan University, United States \\ *Corresponding author: Center for Excellence in Education, 132-L EHS Building, Central Michigan University, Mt \\ Pleasant MI 48859, United StatesＥ-mail: franc1rw@cmich.edu
}

Received: November 2, 2012

Accepted: November 18, 2012

Online Published: December 5, 2012

doi:10.5430/wje.v2n6p32

URL: http://dx.doi.org/10.5430/wje.v2n6p32

\begin{abstract}
Since the publication of Scholarship Reconsidered: Priorities of the Professoriate (Boyer, 1990) many changes have taken place in higher education in America. However, how have faculty perceptions of aspects of the professoriate such as teaching, research, publishing, administration, quality, and areas of interest, changed in the twenty-plus years since the initial research on this topic. This project provides an overview and insight in the current concerns of faculty with respect to promotion and tenure issues. The findings suggest a number of changes have taken place in the way scholarship is perceived by faculty. Publishing still maintains a significant role in decision-making about tenure and promotion and there is still a significant difference in the perception of factors in achieving tenure and promotion between research institutions and liberal arts institutions. There are differences between tenured and non-tenured faculty in concerning what constitutes appropriate scholarship. The scholarship of teaching is seen as important by faculty and yet most have indicated they have little formal teacher training. In both research and liberal arts institutions research and grant writing are seen as important, but there is also a concern that these activities detract from the primary role as a teacher.
\end{abstract}

Keywords: Boyer; Professoriate; Scholarship; Teaching; Tenure

In 1990, Dr. Ernest L. Boyer authored the seminal work on the nature of the professoriate, Scholarship Reconsidered: Priorities of the Professoriate (1990). Boyer developed his research around three central questions: What does it mean to be a scholar? What is the fundamental nature of scholarship? What specific activities carried out by the professoriate should be considered scholarship? Boyer believed answers to these questions would help create a faculty reward system that would meet the challenges of a student body that was demanding excellence in teaching; an end the dissatisfaction of faculties who were unhappy with the existing criteria for assessing them; and would solve the confusion in institutions of higher learning over their goals and the division that that this confusion created.

\section{Literature Review}

Boyer's interests in the role of professors in universities can be traced to the 1950s. After the Second World War there was an increased interest in research among university scholars. Although this research could be seen as a positive movement, in general, it may also be seen to have a negative influence on teaching in colleges and universities. The role of the professor had been seen as one of teaching, research, and service but in the 1950s teaching and service became less complementary and discussions turned around the question of teaching or research. By the 1960s universities began to see their status was based on research more than teaching. Jacques Barzun (1968) posited the belief that scholarship was the criterion for promotion and tenure rather than teaching and that a poor researcher were rewarded better than a good teacher. The new emphasis on research led the Carnegie Foundation to differentiate between traditional universities, and those which it defined as primarily research institutions (Theall, 2009)

It was as President of the Carnegie Foundation for the Advancement of Teaching that Boyer carried out his research. Boyer's report was based on data on existing practices collected from thousands of university and college educators and led to a clarification of beliefs about the concept of scholarship and expanded the view of scholarship 
to include not only scientific discovery through traditional research but scholarship of integration by making interdisciplinary connections, application to the real world, and teaching both the content and the teaching pedagogy to students and colleagues.

Boyer's work told the story of the changing role of university faculty and led both teachers and institutions to reconsider and define their roles and priorities (Starr-Glass, 2011). Boyer attempted to restore teaching as a major faculty activity, but also hoped to "encourage creativity and diversity within the professoriate, bringing renewal to higher learning institutions and ultimately to society" (Lunsford, Union University Review).

Nineteen-plus years have passed since Boyer published his findings. It is our intention to revisit Boyer's research and examine whether his work has led to changes in the ways the professoriate is viewed and the ways in which scholarship is now valued.

Evidence of the way in which Boyer's work has been embraced by the educational community can be found in the organizations that have been developed based on his ideas. The Ernest L. Boyer Center based at Messiah College in Pennsylvania offers courses based on Boyer's philosophy and is also a center for research data on Boyer.

In 1999 the University of Saskatchewan created the Gwenna Moss Center for Teaching Effectiveness which bases its philosophy of university teacher development on Boyer's work. In 1998 the Carnegie Foundation created the Carnegie Academy for the Scholarship of Teaching and Learning (CASTL) as a center to build on the work of Boyer and the follow up work by Charles Glassick et al (1997). The focus of the Academy is on teaching as scholarly work and the challenge of making teaching a more public activity that is open to evaluation and where best practices can be made available to others.

Much of the scholarly work that has followed Scholarship Reconsidered: Priorities of the Professoriate has been concerned with defining and implementing Boyer's ideas. Glassick defined the goal of Scholarship Reconsidered: Priorities of the Professoriate "as being to move beyond the debate about 'teaching versus research' as faculty priorities and give to scholarship a broader more efficacious meaning" (1997). Glassick focused on the nature of scholarship and the elements of scholarship that are common to discovery, integration, application, and teaching, and other researchers have considered the need to develop effective assessments of scholarship ( Del Favero, 2002; Lawrence, 2002).

Research on service as scholarship has led to a number of concerns. One related concern is the unclear criteria for advancement that has led to a devaluation of service as an important measure in the promotion process (O'Meara, 2002; Del Favero, 2002). Further, there is a concern that where changes in tenure and promotion policies the result has been an increased workload for faculty, including increased expectations for research (O'Meara \& Rice, 2005; Huber, 2005). Rather than balancing teaching, service, and research as elements of scholarship, institutions are simply asking more of faculty members in every area.

Perhaps the most significant question concerning Boyer's work is whether Scholarship Reconsidered: Priorities of the Professoriate has had an impact on the value of multiple forms of scholarship in making tenure and promotion decisions. It would seem that the only way to answer this question is to collect data from faculty members at institutions across the country in much the same way as Boyer collected data in 1990. In Faculty Priorities Reconsidered: Rewarding Multiple Forms of Scholarship (O'Meara \& Rice, 2005) the editors have attempted to answer this question by surveying chief academic officers at four-year colleges as to institutional changes in how scholarship is valued. Although the results of this research are valuable, they are based on data from a specific group of institutions that have already made changes in policy and want to share their results.

The question of how faculty in universities throughout the United States view scholarship, and their perception of the requirements for tenure and promotion requires a data collection that is more comprehensive. It is our intention to follow the Boyer research model to complete research on a national scale that will give indications of how faculty are perceiving their roles and activities, and gain insights into the current status of the American Professoriate.

\section{Research Methodology}

The intent of this research was to replicate Dr. Ernest L. Boyer's 1990 work on the nature of the professoriate, Scholarship Reconsidered: Priorities of the Professoriate. Therefore, the survey instrument used in our research incorporated the exact survey questions used by Boyer. Additional questions were inserted at the conclusion of the survey to elicit demographic information for comparison of regional and national similarities and differences of requirements in scholarship, teaching and institutional accreditation from the data gathered. The survey was 
organized for dissemination by email through the use of SurveyMonkey.com software program. All requirements for use of the SurveyMonkey.com web-based email survey program were agreed to and followed by the authors of this research.

The sample for the survey was randomly chosen from colleges, universities and community colleges located within the United States and listed in the website, www.50states.com/colleges. Five colleges and universities were randomly chosen within each of the 50 states and were categorized as follows: three selections were 4-year public institutions, one selection was a 4-year private institution, and one selection was a 2-year community college. Once the college or university was identified, then an academic department within the identified institution was randomly selected and five faculty members within the identified department were randomly chosen to receive the survey. The institutional email addresses of the selected faculty from each identified college or university were loaded into the SurveyMonkey.com software program for the distribution of an email to introduce the researchers, state the goal of the research, and provide a website address in which the respondent could access the survey instrument.

This introductory email was sent to the nearly 1250 randomly selected college and university faculty asking them to participate in the survey. The original number of identified faculty was reduced to 1118 soon after the initial email request for participation in the survey was sent. Upon receiving our email request, some of the identified sample returned an email stating they wanted their email address to be removed from the list; while other identified faculty had retired, moved or for other reasons unknown left the college or university to which they were employed. Two weeks after the original email was sent to the identified survey sample, a second email was sent to the individuals who did not respond to the first email. This second email reminded the individuals of our request, asked if they would be willing to respond to the survey, and provided the MonkeySurvey.com website for the survey a second time. Two weeks following the second email request a third request was sent which was similar in content to the second email. Six weeks after the initial email was sent to the identified individuals who received the survey, the website was closed and the data was organized for review and analysis using the SurveyMonkey.com software. Of the 1118 faculty who received the survey, $286(25.6 \%)$ individuals fully completed the survey and $37(3.3 \%)$ individuals partially completed the survey for a total participation of $323(28.9 \%)$ individuals.

\section{Discussion}

The results of the survey provide several interesting insights into the perceptions of higher education faculty across the nation. These insights have been divided into two areas. First, there is a comparison between the original Boyer research and the current project with comparisons between items related to promotion and tenure, publishing and research, and service. In addition, the second is an analysis of the data collected in the current project that indicates faculty perceptions between different types of institutions, faculty rank, and tenure.

\subsection{Insights on scholarship}

When comparing the data in Table 1 from 1978 and 2008, several items become apparent. Faculty participating in the initial (1978) project indicated that the three items that carried the greatest weight in earning promotion and tenure included: number of publications, student evaluations of teaching, and grants funded. Other categories also demonstrating a high level of weight included: recommendations of outside faculty; observations by peers and administrators; and recommendations from other faculty from within the institution. This is not a surprising finding with respect to research. However, there were differences when the 2008 survey is used for comparison as demonstrated in Table 1. In the 2008 survey, data indicated that the three items that carried the greatest weight included: number of publications, number of grants awarded, and recommendations of other faculty within the institution. 
Table 1: Perceptions by Faculty on "Promotion and Tenure" for Items Rated "Very Important"

\begin{tabular}{llll}
\hline & 1988 & 2008 \\
Perceptions of Faculty Rated "Very Important" & $(\%)$ & + +/- \\
\hline Number of publications & 28.2 & 35.8 & + \\
Recommendations from outside scholars & 21.8 & 13.4 & - \\
Research grants received by the scholar & 21.2 & 27.8 & + \\
Reputations of publishers & 18.4 & 24.7 & + \\
Recommendations from other faculty within the institution & 20 & 28 & + \\
Student evaluations of courses taught & 28 & 18 & - \\
Lectures or papers delivered at professional conferences & 7.6 & 28 & ++ \\
Published reviews of scholar's books & 4.8 & 8.8 & + \\
Service within the scholar's discipline & 8.8 & 8.4 & - \\
Observations of teaching by colleagues or administrators & 20.4 & 16.7 & - \\
Service within the university community & 14.4 & 8.7 & - \\
Recommendations from current or former students & 13.4 & 12.3 & - \\
Academic advisement & 6 & 7 & + \\
Syllabi for courses taught & 9.2 & 18.7 & + \\
\hline
\end{tabular}
“_." = Decrease by $<10 \%$, “+” =increase by $>10 \%$

This change in order demonstrates a shift in the perception of faculty. This shift is from a reliance on traditional publications and a movement toward what Boyer contended was important for scholarship. This includes the active participation by others in the scholarship process.

It should be noted that some areas increased in the perceived weight in promotion and tenure decisions, such as number of publications; grants awarded; reputation of publisher; lectures and papers delivered at professional conferences; and syllabi for courses taught. While other areas decreased in their perceived weight, such as, recommendations from outside scholars; student evaluations; observations of teaching by colleagues and administrators; and service within the institution.

Faculty consistently recognized the role of research and publications in achieving tenure. An overwhelming majority indicated the great difficulty faculty members have in achieving tenure without publications. However, faculty members also indicate a belief that research and publications are far more important than grants in the tenure process.

Faculty indicated that the quality and reputation of the publication is far less important than the actual number of publications generated in the tenure process. Almost one half of faculty reported that there is no qualitative measure of the level of publications used in earning tenure. In other words, the reputation of the publication did not matter; only that the faculty had published somewhere.

While only $38 \%$ of faculty indicated that research was their primary focus, $21 \%$ indicated they have more than 11 publications in refereed journals as shown in Table 2 . Over $85 \%$ of faculty indicated they were currently working on a scholarly project and 57\% indicated they have published a scholarly work with at least one colleague.

Table 2: Comparison of Faculty Activities

\begin{tabular}{llll}
\hline List of Faculty Activities & $\begin{array}{l}1988 \\
(\%)\end{array}$ & $\begin{array}{l}2008 \\
(\%)\end{array}$ & + -- \\
\hline Indicate multidisciplinary work should be considered scholarship. & 23 & 34 & +11 \\
Indicate research grants are important in achieving tenure. & 26 & 18 & -8 \\
Have 11 or more publication in refereed journals. & 29 & 21 & -8 \\
Have publications in refereed journals. & 84 & 79 & -5 \\
Indicate publications with colleagues. & 51 & 57 & +6 \\
Indicate grants are becoming harder to obtain. & 46 & 55 & +6 \\
Indicate current involvement in scholarly projects. & 91 & 87 & -4 \\
\hline
\end{tabular}




\subsection{Insights on service}

Faculty indicated that service within the institution is an important factor in achieving tenure. This service typically is in the form of committee membership and departmental activity. In addition, faculty indicated that service in professional organizations and content-based associations is important in achieving tenure. However, less than half of faculty indicated that advising students is an important factor in achieving tenure. This does not indicate that academic advising is not important. Rather, it indicates that this activity is not considered in the tenure process.

\subsection{Differences in Perceptions}

Within current institutions there appears to be a great variety of perceptions of the common items related to promotion. When respondents indicated the current status of their institutions related to scholarship, teaching, and service, a number of statistically significant differences became apparent. There are a number of significant differences in data between doctorate-granting/research institutions and comprehensive/liberal arts institutions.

The differences between research institutions and comprehensive/liberal arts institutions were apparent in a number of areas. Significant differences in results were indicated between the publication requirements, the inclusion of multidisciplinary work as scholarship, the number of publications required for promotion or tenure, input from other faculty in the promotion and tenure process, and the importance of presentations at professional conferences.

Even with the differences, there were similarities between research institutions and comprehensive/liberal arts institutions. These included the use of student evaluations in the promotion and tenure process and the idea that service to the institution was important.

In addition, differences between faculty ranks, not explored by Boyer in the original research project, reflect a difference in perception between those faculty members who have earned tenure or promotion, and those who have not (Table 3). There are statistical differences between full-professors and associate/assistant professors with respect to appropriateness of publication requirements, the use of multidisciplinary as scholarship, and presentations at conferences as scholarship. Although differences appear when comparing to full-professors, no differences appeared when comparing between associate and assistant professor ranks.

Table 3: Comparing Factors for Earning Promotion and Tenure for Different Faculty Ranks and Institution Types

\begin{tabular}{llll}
\hline Factors for Earning Promotion and Tenure & $\begin{array}{l}\text { Rank } \\
\text { (Full vs. associate and } \\
\text { assistant professor) }\end{array}$ & $\begin{array}{l}\text { Research vs. liberal } \\
\text { arts/ } \\
\text { comprehensive } \\
\text { institution }\end{array}$ & $\begin{array}{l}\text { Associate } \\
\text { assistant professor }\end{array}$ \\
\hline $\begin{array}{l}\text { Publication requirements are appropriate } \\
\text { Multidisciplinary work should be considered } \\
\text { in scholarship }\end{array}$ & $\mathrm{X}$ & $\mathrm{X}$ & Agree - No \\
$\begin{array}{l}\text { Faculty agree on standards of good } \\
\text { scholarship }\end{array}$ & $\mathrm{X}$ & $\mathrm{X}$ & Agree - Yes \\
$\begin{array}{l}\text { The number of publications is important in } \\
\text { earning tenure at my institution }\end{array}$ & Agree - Yes & $\mathrm{X}$ & Agree - No \\
$\begin{array}{l}\text { Student evaluations are important in earning } \\
\text { tenure at my institution }\end{array}$ & $\mathrm{X}$ & Agree - Yes & Agree - Yes \\
$\begin{array}{l}\text { Recommendations from other faculty are } \\
\text { important in earning tenure at my institution }\end{array}$ & Agree - Yes & $\mathrm{X}$ & Agree - Yes \\
$\begin{array}{l}\text { Service to the institution is important } \\
\text { Presentations at conferences are important }\end{array}$ & Agree - Yes & Agree -Yes & X \\
\hline
\end{tabular}

$\mathrm{X}=$ Statistical Difference

There are a number of statistical differences between institution types with respect to teaching. These include the importance of student evaluations, faculty interest in their primary role, and the use of faculty perceptions in earning promotion and tenure. And yet, there is agreement by the respondents with respect to the use of teaching effectiveness as the primary criterion for promotion, that student evaluations are important in the promotion and 
tenure process, that faculty have had little or no formal training in teaching, and faculty use few of the practices identified by Marzano's group (2011) as being effective for classroom instruction.

Table 4: Statistical Differences between Institution Types with Respect to Measures of Teaching for Promotion

\begin{tabular}{|c|c|c|c|}
\hline Measures of Teaching for Promotion & $\begin{array}{l}\text { Research vs. liberal } \\
\text { arts/ } \\
\text { comprehensive } \\
\text { institution }\end{array}$ & $\begin{array}{l}\text { Rank } \\
\text { (Full vs. associate and } \\
\text { assistant professor) }\end{array}$ & $\begin{array}{l}\text { Associate vs. } \\
\text { assistant professor }\end{array}$ \\
\hline Student evaluations are important & Agree - Yes & Agree - Yes & Agree - Yes \\
\hline $\begin{array}{l}\text { Teaching effectiveness should be the primary } \\
\text { criterion of promotion of faculty }\end{array}$ & Agree - No & Agree - No & Agree - No \\
\hline My interests lie primarily in teaching & $\mathrm{X}$ & $\mathrm{X}$ & Agree - Yes \\
\hline $\begin{array}{l}\text { Student evaluations are important in earning } \\
\text { tenure at my institution }\end{array}$ & Agree - Yes & $\mathrm{X}$ & Agree - Yes \\
\hline $\begin{array}{l}\text { Recommendations from other faculty are } \\
\text { important in earning tenure at my institution }\end{array}$ & $\mathrm{X}$ & Agree- Yes & $\mathrm{X}$ \\
\hline Service to the institution is important & $\mathrm{X}$ & $\mathrm{X}$ & $\mathrm{X}$ \\
\hline $\begin{array}{l}\text { If I had it to do all over again, I would not } \\
\text { become a college teacher }\end{array}$ & Agree - Yes & Agree - Yes & Agree - Yes \\
\hline $\begin{array}{l}\text { Have you had any formal training in courses } \\
\text { in teaching }\end{array}$ & Agree - No & Agree - No & Agree - No \\
\hline $\begin{array}{l}\text { Use of } 5 \text { or more of Marzano's identified } \\
\text { effective teaching strategies }\end{array}$ & Agree - No & Agree - No & Agree - No \\
\hline
\end{tabular}

Full-professors appear to differ from assistant/associate professors in their primary interests and the importance of student evaluations in the promotion and tenure process. In addition, all groups agree that they have had a lack of formal training in teaching or the use of effective classroom instructional processes.

\subsection{Institutional Characteristics}

Other differences are apparent between the institutions represented by the respondents (Table 5). There is a significant difference between those who are nationally accredited and those who are not when comparing the institution type. In addition, there is a difference in faculty union/association membership between public and private institutions.

Table 5: Statistical Differences between Institution Types with Respect to National Accreditation

\begin{tabular}{ll}
\hline Differences between Institutions & $\begin{array}{l}\text { Research vs. liberal arts/ } \\
\text { comprehensive institution } \\
\text { (all respondents) }\end{array}$ \\
\hline Accredited by NCATE or TEAC & $\mathrm{X}$ \\
Member of a faculty union & $\mathrm{X}$ \\
Public or private institution & $\mathrm{X}$ \\
Formal training an aspects of teaching & Agree - No \\
Service to the institution is important & Agree - Yes \\
If I had it to do all over again, I would become a college teacher & Agree - Yes \\
Research detracts from my primary teaching responsibilities & Agree - Yes \\
Grant writing detracts from my primary teaching responsibilities & Agree - Yes \\
\hline
\end{tabular}

$\mathrm{X}=$ Statistical Difference

Another similarity that exists between the different types of institutions relates to the perception of research. Faculty at all institutions indicated that research and grant writing detract from their teaching performance. In addition, faculty perceptions indicate that with all of the issues detracting from teaching, they would still make the choice to become a college level faculty member. 


\section{Conclusions}

The research indicates that Boyer's work has led to ongoing research by both individuals and institutions. Institutions such as Messiah College, Saskatchewan University and the Carnegie Academy for the Scholarship of Teaching and Learning not only advocate for Boyer's beliefs, they continue to expand on them. Individual scholars have focused on specific areas of Boyer's work. Charles Glassick has worked on developing a broader view of scholarship and on making teaching a more public activity while scholars such as O'Meara (2002), Del Favero (2002), Huber (2005) have research concerns such as the role of service and increased work load for faculty.

The findings suggest a number of changes in the way scholarship is perceived. Publishing still maintains a significant role in decision-making about tenure and promotion and there is still a significant difference in the perception of factors in achieving tenure and promotion between research institutions and liberal arts institutions. There are differences between tenured and non-tenured faculty in concerning what constitutes appropriate scholarship. The scholarship of teaching is seen as important by faculty and yet most have indicated they have little formal teacher training. In both research and liberal arts institutions research and grant writing are seen as important but there is also a concern that these activities detract from the primary role as a teacher.

The research on the nature of the professoriate and the nature of scholarship continues to grow. The challenge seems to be to inculcate that research into the culture of colleges and universities. Although faculty-believe in the research, implementation is limited until it becomes institutional and consistent.

\section{References}

Barzun, Jacques. (1968). The American University. New York, NY: Harper and Row.

Boyer, Ernest L. (1990). Scholarship Reconsidered: Priorities of the Professoriate. Princeton, NJ: Carnegie Foundation for the Advancement of Teaching.

Del Favero, Marietta. (2002). Assessment criteria, performance standards and quality, assessment tools, the portfolio as an assessment tool. Faculty Research and Assessment of Scholarship Performance. Retrieved from http://education.stateuniversity.com/pages/1971/Faculty-Research-Scholarship-Assessment.html

Glassick, Charles, E. (January, 1997) Scholarship assessed: a special report on faculty evaluation. AAHE Conference on Faculty Roles and Rewards. San Diego, California.

Glassick, Charles, E., Huber, Mary Taylor, \& Maeroff, Gene, I. (1997). Scholarship Assessed: Evaluation of the Professoriate. San Francisco, CA: Josse-Bass.

Huber, M. T., \& Hutchings, P. (2005). The Advancement of Learning: Building the Teaching Commons. San Francisco, CA: Josse-Bass.

Jaschik, Scott. (2009). Has scholarship been reconsidered? Inside Higher Education. Retrieved from http://insidehighered.com

Lawrence, Janet. (2002). Historical background, factors affecting scholarly performance, defining scholarship, measurement, scholarly activities and products. Faculty Research And Assessment of Scholarship Performance. Retrieved from http://education.stateuniversity.com/pages/1970/Faculty-Performance-Research Scholarship.html

Lunsford, Matt. (2009). Book Review of Scholarship Reconsidered: Priorities of the Professoriate. Retrieved from http://www.uu.edu/centers/faculty/bookreviews/lunsford.htm

O’Meara, Kerry Ann \& Rice, Eugene R. (2005). Faculty Priorities Reconsidered. San Francisco, CA: Josse-Bass.

Starr-Glass, D. (2011). Reconsidering Boyer's "reconsideration" paradigms, sharing, and engagement. International Journal for the Scholarship of Teaching and Learning, 5(2).

Tagg, J. (2010). Dispelling the fog of learning through SoTL. International Journal for the Scholarship of Teaching and Learning, 4(2). Retrieved from http://academics.georgiasouthern.edu/ijsotl/v4n2/invited_essays/PDFs/_Tagg.pdf

Theall, Michael. (2009). College Teaching - A short history, the professional roles and responsibilities of college teachers. The State University.com Education Encyclopedia. Retrieved from http://education.stateuniversity.com/pages/1866/College-Teaching.html 